\title{
An Empirical Study on Demand Factors for Life Insurance and Saving Deposits using ARDL-Bounds: the case of Korea and Japan
}

\author{
Eun-yub Park and Young-jae Kim
}

\begin{abstract}
This paper investigates the relationship between both new premiums of life insurance and savings deposits and macro-economic variables which including stock index, exchange rate, industrial productivity index(IPI), and interest rate, in Korea and Japan. Based on the results of this empirical test, this paper tries to find out demand elasticity of both life insurance and savings deposits. To accomplish this paper, ARDL(Auto Regressive Distributed Lag)-Bounds is employed with monthly data, covering from 2011 and 2016. The overall results of this tests showed that demand for insurance was more elastic than the savings deposits of both Korea and Japan. Insurance demand elasticity' response to exchange rate and interest rate is high in Koreas' long-term, while this response to IPI is large and highly significant in Japan. Which helps to explain that demands of insurance and savings are influenced in the policy such as interest rate in Korea, slightly differently, it' demand is more dependent on the real economy such as IPI.
\end{abstract}

Keywords - ARDL, Elasticity, Insurance, Japan, Korea, Savings Deposit

\section{INTRODUCTION}

$\mathrm{T}^{\mathrm{N}}$ recent years, there has been an increase volatility by worldwide recession since the global financial crisis. For this reason, forecasting for demand of each corporate were difficult. Especially, the global insurance industry is more affected by global economic volatility such as weak economic growth, low inflation rates, and near-zero interest rates. Some of these was transition from real sector to financial sector. And directly or indirectly, reducing the growth rate of life insurance industry.

The insurance industry is acquisition a dangerous that the individual and corporate can not be prepare themselves in order to living unit is able to economic activities freely. Recently, property insurance industry its guarantees objects has been maintain stable growth despite the low growth of the global economy environment. However, in the case of life insurers faced rapidly decline the return on investment to lower interest rates.

In addition, it has pointed out that low interest rates are the biggest factor to threaten the insurance industry. These interest rate risk was excused as it could not respond positively to the possibility of future interest rate rises. This is due to

Eun-yub Park, Pusan National University, Busan, 46241 South Korea (e-mail : rarara3028@gmail.com ).

Young-Jae Kim, Pusan National University, Busan, 46241 South Korea (e-mail : kimyj@pusan.ac.kr ). characteristics of the insurance corporate. Basically, if it is difficult to guarantee a return to policyholder then policy holder will cancel the insurance contract it also can excused the liquidity problems of insures.

Further, the volatility expansion of interest and financial sector is related to banking yields by influencing the duration of the assets and liabilities. These changes were occurred to mergers and acquisitions of insurance corporate which is very higher the trend than other industries.

Insurance companies and banks have been used to access easily and frequency trading highly in economic activity of the private sector. Instability of these industries produces an significant social problem. For ensure the stability of the industry, each insurers and banks manage the financial internally. But due to risk volatility, these may face the possibility that fund is not ensured for minimum revenue.

This study attempts to analyze the demand factors of life insurance and savings in Korea and Japan firstly caused by the similarity of the social and cultural characteristics. Furthermore, it makes possible to predict also it can determine the best business strategy although each industry is committed to manage for stable and sustainable internally that analyzing the demand factors with macroeconomic variable.

Briefly, similarities of characteristic of two countries can be compared the difference between of insurance inclinations. The purpose of coverage was investigated to guarantee retirement as proceeding the difficulties of life and aging in Korea. Likewise, the demand has been continued the disease and retirement funds to prepare for entering an aging society despite the decline in generation subscription rate since 1994. Also, The flow of two countries have been harmonized with diversification of sales channels, increase of younger consumers, and changing of population structure from low birth rates. As a proof above, only the Japanese insurance market is very large compared to Korea in terms of the economic environment but similarly recorded the number of subscription per household to about four. And average annual premium expenditures was 3,554 dollars per capita and ranked 14th at world insurance market in Japan. In case of Korea, 3,034 dollars and 18th.

Insurance preferences which means premiums ratio about GDP was $11.42 \%, 10.82 \%$ and ranked world's 6 th, 8 th each countries of Korea, Japan. These reason is not only the high affinity for insurance but increasing about aging and recession. Demand elasticity of insurance and savings deposit is predicted low about economic fluctuations as recognized a long-term 
products. However, analysis and forecasts for both the short-term and the long-term are required to continuous stability of corporation.

Therefore, the aim of this study is to analysis the demand factors of life-insurance and savings deposit attributable to changes in macro-economic variables using dynamic method, ARDL model. Specifically, first, we analyzed the short-term and long-term relationship between each industry and macro-economic variables using ARDL model applied a time difference. Secondly, we predicted using the out of sample. In addition, it presents the RMSE to compare with Bayesian VAR model to ensure the robustness of the model.

The overall structure of the study takes the form of five sections, including this introductory section. Section Two begins by laying out the previous studies associated with insurance demand factors. The third Section is concerned with the methodology used for this study. In Section four, we describes the empirical results. And finally, the conclusion gives a brief summary and critique of the findings, and includes a discussion of the implication of the findings to future research into this area.

\section{II.LITERATURE REVIEW}

Advanced research on life insurance demands can be affected by tradition, religion, and culture. Advanced research techniques are needed through classifying the causes since each country could have different factors for insurance demand and also diverse factors could be mixed. Factors for insurance demands can be usually classified by economic, social cultural and demographic factors.

Economic factors can be defined as economic growth, inflation, unemployment rate, income, stock price, and interest rate.

Lee Gi Hwan (1997), by using data from 16 OECD countries analyzed life insurance industry and international competitiveness, investigated that productivity of insurance practician, insurance infiltration rate, and total market value in contrast of GDP are statistically attentive variables.

Hwang Jin Tae, Seo Dae Gyo (2010) analyzed relation between variable annuity, variable universal first premium and macroscopic variable through VECM; claimed that KOSPI quotient and interest rate have a great role on variable annuity and for variable universal, unemployment rate impact contributed greatly. It was also revealed that unemployment rate had positive response on variable annuities and had negative response on variable universal insurance. Categorizing insurance characteristics, Lee Jung Sang (2009) analyzed guaranteed insurance and saving insurance by setting the relation of oil price, exchange rate, interest rate, and money supply as uncertainty of macroeconomic and future expectation variables. Nam Sang Wook (2006) analyzed actual proof of causal link between insurance and GDP, saving amount, interest rate, price and unemployment rate for 25 years from 1980 to 2004 for 16 advanced countries.

According to foreign literature, Hammond, Houston, Melander (1967) analyzed the correlation between insurance premium and variables through regression analysis, Beenstock (1998) revealed that there is positive correlation between damage premium and income. Also, for factor analysis on insurance industry, rapid growth in insurance market after World War II, Brown and Kim carried out demand analysis of life insurance premium and insurance premium of income. There was earning of the fact that demand for life insurance has positive relation to income and that as economic grew, insurance industry grew.

Social cultural factors are religion, ethnicity, social security and educational standard etc. Brown and Kim (1990) said that in Islamic countries there were negative effects on insurance demand through insurance demand analysis. There were a lot of cases where absolute religion had most powerful effect on deciding insurance demand. For case of Korea, recommendation from an insurance planner from regionalism, school relations and kinship were important factors in insurance determinants of demands. Strong Social security and political stability provided the cause of lowering dependency in private insurance.

Population statistics and insurance factors are size of the family, age, gender, expected lifespan, and rate of economically active population. These were considered variables in insurance industry. Lee Soon Jae, Yang Sung Moon (2011) analyzed the life insurance demand factors by using life insurance detailed type panel data. Truett and Truett (1990) compared life insurance demand in USA and Mexico through regression analysis; age, education standard, income level had effect on life insurance demand and income for Mexico and householder for USA had positive relations. Study on savings were done by Jung Hong Joo (2000); causal link between GNP, savings, and insurance were analyzed through VAR modeling and integration and found that GNP and total savings advanced life insurance.

To overcome the limit of analyzing the demand factor using most of the existing studies' current variable relation term, this study used ARDL model considering the dependent and independent variable time difference to include economic environmental changes in the former part. Also it allowed comparing by assaying the flexibility of life insurance demand and household saving demand that faces identical environment. Insurance and deposit demand causes are due to individual's desire and surrounding environmental changes, anthropologic aspects and sales person's ability also have a lot of affects but they are difficult to predict. Due to these causes, both demand analysis are done by a lot of economic factors. This will provide an opportunity to enable the stability of financial safety as well as sales strategy and product development according to economic fluctuations through objective data which allows the prediction of demand business wise. This study will provide useful information by adding duration of the impact, deviation and period of adjustment to qualitative research about correlation between demand for insurance and macroeconomic variables from existing studies.

\section{METHODOLOGY AND MODEL}

Autoregressive distributed lag model (ARDL) of the dependent variable and the explanatory variable autoregressive model is considered to lag. $\mathrm{P}$ is the time difference between autoregressive $\operatorname{AR}(p)$ and $q$ variables with the time difference 
$\operatorname{ARDL}(p, q)$ can be expressed as. It represents a general form as follows:

$$
\begin{aligned}
& y_{t}=\mu+\beta_{0} x_{t-1}+\cdots+\beta_{q} x_{t-q}+\gamma_{1} y_{t-1}+\cdots \\
& +\gamma_{p} y_{t-p}+\varepsilon_{t}
\end{aligned}
$$

This is a time lag for a finite number(q) contains. ARDL model, but if you go back infinitely into the past, including the time lag can be transformed into a model. ARDL $(1,1)$ model in the $\left|\gamma_{1}\right|<1$, assuming as (2) is to be able to display.

$$
y_{t}=\alpha+\beta_{0} x_{t}+\sum_{i=1}^{\infty} \gamma_{1}^{(i-1)}\left(\beta_{1}+\gamma_{1} \beta_{0}\right) x_{t-1}+\mu_{t}
$$

Above equation is $\alpha=\mu /\left(1-\gamma_{1}\right)$ and $\mu_{t}=\varepsilon_{t}+\gamma_{1} \varepsilon_{t-1}+\gamma_{1}^{2} \varepsilon_{t-2}+\ldots$ Equation (2) does not have finite block that (3) as an infinite distributed lag model (infinite distributed lag model)

$$
y_{t}=\alpha+\sum_{i=0}^{\infty} \beta_{i} x_{t-i}+\mu_{t}
$$

If $\mathrm{p}, \mathrm{q}$ large enough values then $\operatorname{ARDL}(\mathrm{p}, \mathrm{q})$ can be close to the infinite difference in the distribution features.

Where the long-term impact on the change of the weight difference is showing.

Thus, the long-term impact of the on going changes to the long-term multiplier is $\sum_{i=0}^{\infty} \beta_{i}$

In this study, based on the ARDL(p,q1,q2, ..., qK)model variables used in the empirical analysis I (1) was set to.

Change in the independent variable on the dependent variable, the impact is distributed over time, depending on the estimated coefficients. Find out how.

Using a multiplier factors and long-term demand elasticity and long-term economic relations compare. Used in this study, the generalized ARDL (p, q1, q2, .., qK) model is the same as $\Phi(L, p) y_{t}=\sum_{i=1}^{k} \beta_{i}\left(L, q, x_{i}+\delta \omega_{t}+\mu_{t}\right.$

Where $\mathrm{L}$ is the lag operator, $\mathrm{p}=0,1,2, \ldots \mathrm{m}, \mathrm{q}=0,1,2, \ldots \mathrm{n}, \mathrm{i}=$ $1,2, \ldots \mathrm{k}$, the constant term or a time variable as a deterministic variable indicates.

At this time, the one was selected at number of $(m+1)^{k+1}$, ARDL'model. It was applied to minimize the value of the time difference on Akaike information criterion (AIC) Schwarts Baysian Criterion (SBC). Finally it was selected less lag model if the AIC values that contain similar.

In this study, life insurance and savings elasticity of the demand factors used to estimate the ARDL model (4). Adjustment process to identify short-term non-constrained error correction model (unrestricted error correction model, UECM) estimation of (5).

This can be expressed by replacing as representing the life insurance demand equation (4) and (5).

$$
\begin{aligned}
& N P_{t}=\alpha_{0}+\sum_{i=1}^{3} \beta_{1} \text { NP }_{t-i}+\sum_{j=1}^{3} \beta_{2 j} \text { NTEREST }_{t-j} \\
& +\sum_{k=1}^{3} \beta_{3 k}|P|_{t-k}+\sum_{p=1}^{3} \beta_{4 p} F X_{t-p}+\sum_{s=1}^{3} \beta_{5 s} \text { STOCK }_{t-s} \\
& +\sum_{h=1}^{3} \beta_{6 h} \text { UNEMP }{ }_{t-h}+\varepsilon_{t} \\
& \nabla N P_{t}=\alpha_{0}+\alpha_{1} \text { trend }+\sum_{k=1}^{n} \alpha_{2 k} \nabla N P_{t-k} \\
& +\sum_{k=1}^{n} \alpha_{3 k} \nabla \text { INTEREST }_{t-k}+\sum_{k=1}^{n} \alpha_{4 k} \nabla|P|_{t-k} \\
& +\sum_{k=1}^{n} \alpha_{5 k} \nabla F X_{t-k}+\sum_{k=1}^{n} \alpha_{6 k} \nabla \text { STOCK }_{t-k} \\
& +\sum_{k=1}^{n} \alpha_{7 k} \text { DUNEMP }{ }_{t-k}+\theta_{1} \text { NPP }_{t-1}+\theta_{2} \text { NNTEREST }_{t-1} \\
& \left.+\theta_{3} / P I_{t-1}+\theta_{4} \text { FX }{ }_{t-1}+\theta_{5} \text { STOCK }_{t-1}+\theta_{6} \text { UNEMP }_{t-1}\right) \\
& +\varepsilon_{t}
\end{aligned}
$$

Where DEPOSIT is household savings demand factor of Korea, NP is life insurance demand and using premiums of new polices, INTEREST is interest rate, IPI is industrial production index, FX is exchange rate, STOCK is stock Price index, and UNEMP is the unemployment rate.

\section{THE EMPIRICAL RESULTS}

To empirically compare and analyze factors for domestic life insurance demand and deposit demand, life insurance corporation' new premium (NP), bank's 3 year household savings deposits (DEPOSIT), interest rate (INTERSET) based on CD yield (91days), index of industrial production (IPI), exchange rate $(\mathrm{FX})$, the composite price index of stocks (STOCK), and unemployment rate (UNEMP) are used as variables both Korea and Japan. For each variable to secure the stability of analysis and to measure flexibility modulus, other than unemployment rate and interest rate converted to natural logarithms. Analysis periods are from April 2011 to March 2015 , and used monthly data. And to predict the next periods, it applied to April 2015 to March 2016.

Assumption was made by setting the life insurance demand mode as K_NP, and household savings deposit demand model as K_DEPOSIT in Korea. Likewise, it was set capitalized 'J_' as the first letter in the equations of Japan. For empirical analysis, used variables' definitions and basic information are as $<$ Table 1>. 
TABLE I

DEFINITION OF VARIABLES

\begin{tabular}{|c|c|c|c|}
\hline Variable & & Definition & Measurement \\
\hline \multirow{7}{*}{ Korea } & K_DEPOSIT & $\begin{array}{l}\text { savings } \\
\text { deposits }\end{array}$ & $\begin{array}{l}\text { Total household } \\
\text { savings on bank(unit : } \$ 1 \\
\text { million), } \\
\text { Natural logarithm, BOK }\end{array}$ \\
\hline & K_NP & $\begin{array}{l}\text { premiums of } \\
\text { new polices }\end{array}$ & $\begin{array}{l}\text { New policy premium of the } \\
\text { private life insurance } \\
\text { company (unit : } \mathbb{1} 1 \\
\text { million), } \\
\text { Natural logarithm, KIDI }\end{array}$ \\
\hline & K_INTEREST & interest rate & $\begin{array}{l}3 \text { months rate }(\mathrm{CD}) \text {, } \\
\text { BOK }\end{array}$ \\
\hline & K_IPI & $\begin{array}{l}\text { industrial } \\
\text { production } \\
\text { index }\end{array}$ & $\begin{array}{l}\text { All the industrial } \\
\text { production index, } \\
\text { Seasonally adjusted, } \\
\text { Natural logarithm, } \\
\text { BOK }(2010=100)\end{array}$ \\
\hline & K_FX & exchange rate & $\begin{array}{l}\text { Won dollar exchange rate, } \\
\text { Natural logarithm, BOK }\end{array}$ \\
\hline & K_STOCK & $\begin{array}{l}\text { Korea } \\
\text { composite } \\
\text { stock Price } \\
\text { index }\end{array}$ & $\begin{array}{l}\text { KOSPI index, Natural } \\
\text { logarithm, BOK } \\
(1980.1 .4 .=100)\end{array}$ \\
\hline & K_UNEMP & $\begin{array}{l}\text { unemployment } \\
\text { rate }\end{array}$ & Unemployment rate, IMF \\
\hline \multirow{7}{*}{ Japan } & J_DEPOSIT & $\begin{array}{l}\text { savings } \\
\text { deposits }\end{array}$ & $\begin{array}{l}\text { Total household } \\
\text { savings on bank(unit : } \$ 1 \\
\text { million), } \\
\text { Natural logarithm, BOJ }\end{array}$ \\
\hline & J_NP & $\begin{array}{l}\text { premiums of } \\
\text { new polices }\end{array}$ & $\begin{array}{l}\text { New policy premium of the } \\
\text { private life insurance } \\
\text { company(excluded post } \\
\text { office life insurance, unit : } \\
\text { \# } 1 \text { million), } \\
\text { Natural logarithm, LIAJ }\end{array}$ \\
\hline & J_INTEREST & interest rate & $\begin{array}{l}3 \text { month-Market interest } \\
\text { rates } \\
\text { BOJ }\end{array}$ \\
\hline & J_IPI & $\begin{array}{l}\text { industrial } \\
\text { production } \\
\text { index }\end{array}$ & $\begin{array}{l}\text { All the industrial } \\
\text { production index, } \\
\text { Seasonally adjusted, } \\
\text { Natural logarithm, BOJ }\end{array}$ \\
\hline & J_FX & exchange rate & $\begin{array}{l}\text { Dollar yen exchange, } \\
\text { Natural logarithm }\end{array}$ \\
\hline & J_STOCK & $\begin{array}{l}\text { Korea } \\
\text { composite } \\
\text { stock Price } \\
\text { index }\end{array}$ & $\begin{array}{l}\text { Nikkei(225) Natural } \\
\text { logarithm, BOJ, }\end{array}$ \\
\hline & J_UNEMP & $\begin{array}{l}\text { unemployment } \\
\text { rate }\end{array}$ & Unemployment rate, IMF \\
\hline
\end{tabular}

\section{A. Unit root test}

Most of time series data have features of unstable stochastic trend and random walk with drift. If these unstable data are used in analysis, it is possible to obtain a significant regression results from unrelated article. To test the reliability of time series data, existence of unit root has to be tested. In consideration of the tendency of the time and constant term of each variable, ADF (Augmented Dickey-Fuller) and PP (Phillips-Perron) were under testing.
TABLE II

RESULTS OF TEST (ADF AND PP)

\begin{tabular}{|c|c|c|c|c|}
\hline \multicolumn{3}{|c|}{ Variable } & Level & First \\
\hline \multirow{14}{*}{ Korea } & \multirow{2}{*}{ K_DEPOSIT } & $\mathrm{ADF}$ & -1.752 & $-5.002 * *$ \\
\hline & & $\mathrm{PP}$ & -1.562 & $-8.070 * *$ \\
\hline & \multirow{2}{*}{ K_NP } & $\mathrm{ADF}$ & -0.275 & $-8.765^{* *}$ \\
\hline & & $\mathrm{PP}$ & -2.701 & $-8.951 * *$ \\
\hline & \multirow{2}{*}{ K_INTEREST } & $\mathrm{ADF}$ & -2.952 & $-4.415^{* *}$ \\
\hline & & $\mathrm{PP}$ & -2.868 & $-4.380 * *$ \\
\hline & \multirow{2}{*}{ K_IPI } & $\mathrm{ADF}$ & $-7.236^{* *}$ & $-5.410^{* *}$ \\
\hline & & PP & $-7.253^{* *}$ & $-30.755 * *$ \\
\hline & \multirow{2}{*}{ K_FX } & $\mathrm{ADF}$ & -2.363 & $-5.553 * *$ \\
\hline & & $\mathrm{PP}$ & -1.617 & $-4.662 * *$ \\
\hline & \multirow{2}{*}{ K_STOCK } & $\mathrm{ADF}$ & $-4.598 * *$ & $-5.224 * *$ \\
\hline & & PP & $-3.565^{* *}$ & $-7.074 * *$ \\
\hline & \multirow{2}{*}{ K_UNEMP } & $\mathrm{ADF}$ & -2.883 & $-8.995^{* *}$ \\
\hline & & PP & $-3.169^{* *}$ & $-9.002 * *$ \\
\hline \multirow{12}{*}{ Japan } & \multirow{2}{*}{ J_DEPOSIT } & $\mathrm{ADF}$ & -1.545 & $-4.008 * *$ \\
\hline & & $\mathrm{PP}$ & $-9.641^{* *}$ & $-25.804 * *$ \\
\hline & \multirow{2}{*}{ J_NP } & $\mathrm{ADF}$ & $-3.175^{* *}$ & $-4.016^{* *}$ \\
\hline & & $\mathrm{PP}$ & $-16.397 * *$ & $-30.308 * *$ \\
\hline & \multirow{2}{*}{ J_INTEREST } & $\mathrm{ADF}$ & 0.608 & $-6.664 * *$ \\
\hline & & PP & 0.451 & $-6.680 * *$ \\
\hline & \multirow{2}{*}{ J_IPI } & $\mathrm{ADF}$ & $-3.181^{* *}$ & $-10.303^{* *}$ \\
\hline & & $\mathrm{PP}$ & $-4.975^{* *}$ & $-10.137 * *$ \\
\hline & \multirow{2}{*}{ J_FX } & $\mathrm{ADF}$ & -0.913 & $-3.697 * *$ \\
\hline & & $\mathrm{PP}$ & -0.711 & $-5.697 * *$ \\
\hline & \multirow{2}{*}{ J_STOCK } & $\mathrm{ADF}$ & -0.793 & $-6.160 * *$ \\
\hline & & $\mathrm{PP}$ & -0.845 & $-6.106^{* *}$ \\
\hline
\end{tabular}

Note : DEPOSIT, INTEREST and IPI variable of Korea are applied intercept and trend, also UNEMP are applied In japan variable. Other variables are associated intercept. * implies significant at $1 \%, * *$ implies significant at $5 \%$.

$<$ Table 2>is the results of the ADF and PP test based on Mackinnon (1996). Applying the 5\% significance level, unit root test result was mixed with variables I(1) and I(0) In general, the results of the PP test may be more reliable if the results of the ADF test and PP test is different. Therefore, all variables except K_IPI, K_STOCK, J_NP, AND J_IPI determines that the there is a unit root.

\section{B. Bounds test based on UECM Model}

The order of the result variable of unit root test of time series variables $\mathrm{I}(0)$ and $\mathrm{I}(1)$ are mixed, application of Johansen-Juselius co-integration theory of testing hypothesis could generate a statistical flaw thus, it is not reliable. To find the existence of co integration, this study has used LM testing 
which is applied with unrestricted error correction model, UECM to test Bounds. There's no existence of co integration relations if bounds critical values are lower based on F statistics and existence of co integration vector is uncertain if upper bounds critical values are in between and if upper bounds critical values exceed there is existence of co integration relations.

TABLE III

RESULTS OF TEST (ARDL-BOUNDS : WALD TEST)

\begin{tabular}{c|c|c|c|c}
\hline \multirow{2}{*}{ Division } & \multicolumn{2}{|c|}{ Korea } & \multicolumn{2}{c}{ Japan } \\
\cline { 2 - 5 } & $\begin{array}{c}\text { Insurance } \\
\text { demand }\end{array}$ & $\begin{array}{c}\text { Deposits } \\
\text { demand }\end{array}$ & $\begin{array}{c}\text { Insurance } \\
\text { demand }\end{array}$ & $\begin{array}{c}\text { Deposits } \\
\text { demand }\end{array}$ \\
\hline \hline F-value & 6.491 & 4.544 & 4.562 & 8.956 \\
\hline critical values & \multicolumn{2}{|c|}{$\begin{array}{c}\text { lower bounds critical } \\
\text { values I(0) }\end{array}$} & $\begin{array}{c}\text { upper bounds critical } \\
\text { values I(1) }\end{array}$ \\
\hline $5 \%$ & \multicolumn{2}{|c|}{3.47} & \multicolumn{2}{c}{4.57} \\
\hline $10 \%$ & \multicolumn{2}{|c|}{3.03} & \multicolumn{2}{|c}{4.06} \\
\hline
\end{tabular}

Note : 1) Critical values is applied the unrestricted intercept and unrestricted trend of Pesaran, Shin, and $\operatorname{Smith}(2001$, p.301) table C1(v) case V.

2) Independent variable are four.

Also, reliability of coefficient etimates was proved through CUSM (Cumulative sum) testing. CUSUM testing is whether estimation equation has stability in error term of $5 \%$ critical standard, for CUSUM whether it is emitted from zero mean value line. <Figure $1>$ is the result of CUSUM, it is confirmed that odd ratio estimation on Korea premiums seems to be unstable early 2015 especially, this is near the deviation of dispersion of error term strays from $5 \%$ critical. Stability test results of other model has a bit deviation from zero mean value line, therefore we are able to consider that coefficients of estimation equation are stable.
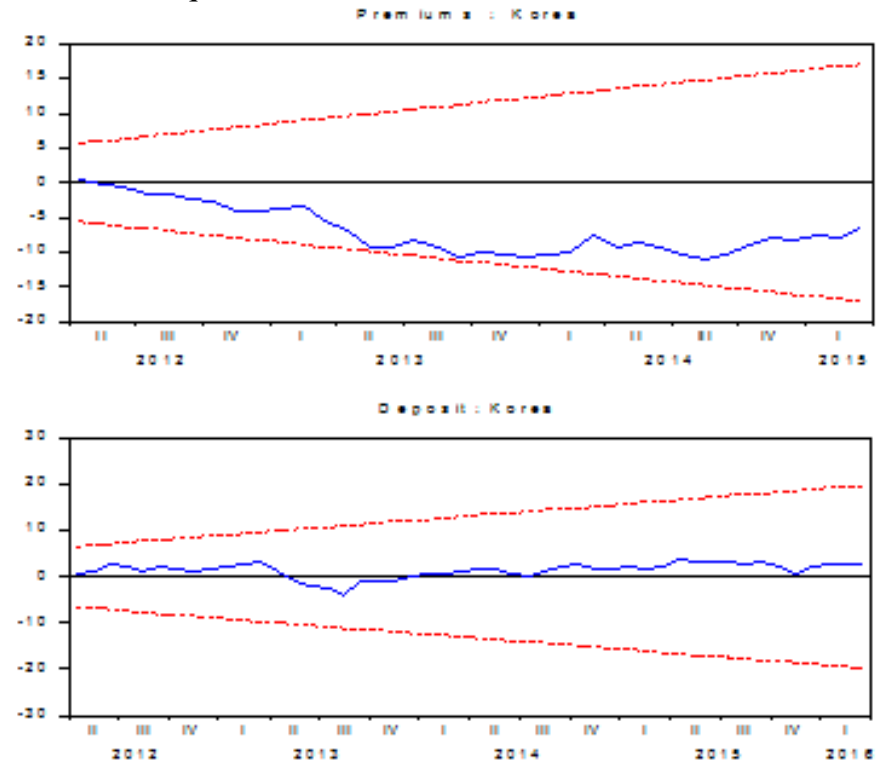
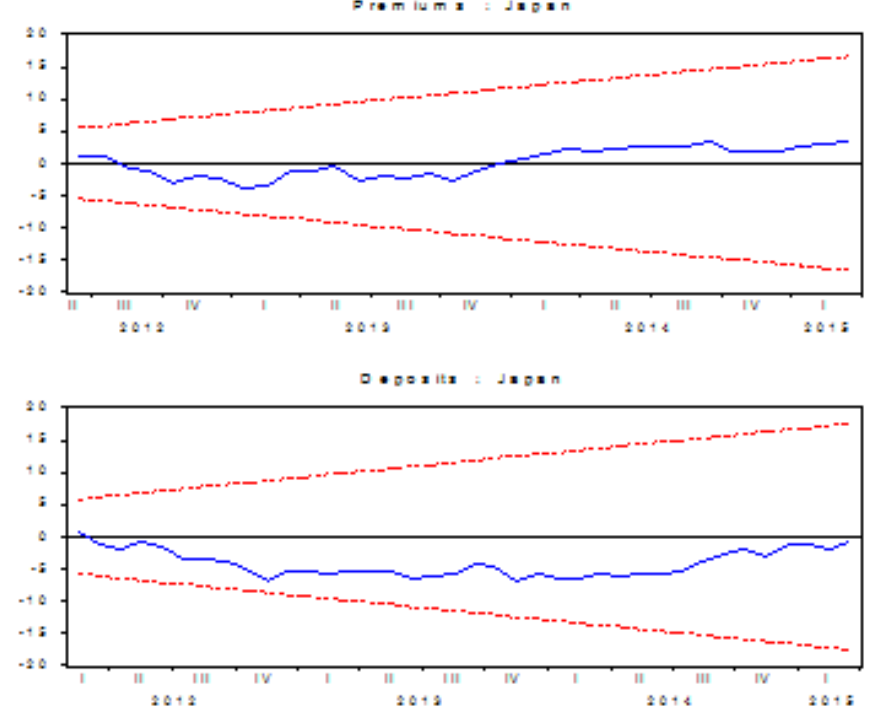

Fig. 1 The result of CUSUM test

Note : The solid line implies CUSUM, dotted line implies 5\% significance

\section{Estimation and analysis of results}

Above testing results are formed by more than 200 assumptions. To estimation the long and short term coefficient, among set ARDL models, based on minimum Akaike information criterion (AIC) and Schwarts Baysian Criterion (SBC) difference between $\mathrm{p}$ and $\mathrm{q}$ was decided. K_NP which is the life insurance demand in Korea is set to $\operatorname{ARDL}(1,1,2,2,0)$, K_DEPOSIT which is the household savings demand in Korea is set to ARDL $(1,1,0,2,1)$, J_NP which is the life insurance demand in Japan is set to ARDL $(2,1,0,1,0)$ and household savings demand model is set to ARDL $(2,1,0,0,0)$.

First, we had to select one variable of IPI and unemployment rate for avoid to multicollinearity. So, the equation was formed using a variable which provided more effective results. For this reason, the variable used except demand for savings in japan is IPI.

Results on estimating long-term coefficient by estimation equation according to optimum ARDL model are as shown in $<$ Table 4>. This study will describe the estimated coefficient as elasticity.

When considering a long-term relationship with variables, demand for insurance shows the most positive elasticity with interest and exchange rate, but it' response is highest as happen temporary shock on IPI in Korea. Exchange rate is an important factor in finance sector especially on small open economy. Exchange rate and demand for insurance are corresponded as the exchange rate are falling by appreciation of Won, which ascends the total guaranteed amount of insurance. But, Savings demand be find as a result of the opposition. In the long-term, demand of insurance for the higher interest rate increases but reduce temporarily. Also, increase of IPI lead the demand for insurance, but it reduces traction in the long-term. The rise of the stock index is decline in the demand for insurance. In particular, the bigger its influence in the long run.

In the case of savings demand in Korea, all variables excluding exchange rate indicates the elasticities of positive. As expected, the elasticity both the short and the long of rising of interest rate and IPI are increase. In contrast, rise of stock index 
lead the demand for savings.

In Japan, demand for insurance is shown to increase against the impact of Yen appreciation. Yen depreciation might also be displayed the result of fiscal and monetary policies of the Bank of Japan. So, the exchange rate will not be able to be a barometer of the Japanese economy. Demand savings and insurance depending on the interest rate changes indicate a negative relationship in the long-term but a positive relationship directly.

The interest rate shock on both insurance and savings demand shows only the elasticity of positive with less than ' 1 ' in short-term. But relationship is change in negative, also elasticities shrink away in long-run.

IPI and unemployment rate are indicated the negative relationship with two demands in all term. This result is different from the Korea on IPI.

The degree of IPI elasticities is extremely high and effective. Demand for insurance even the rise of IPI which represent the economic environment is not increased. One of these causes can expect that instability for the future continually as Japan has experienced recession since decades.

Stock index shocks to savings demand is negative relationship both short and long-term. This result is also different from Korea. Japan had been have high rate of savings, however the attractiveness has gone on savings due to the low interest rate and long-term aging.

TABLE IV

THE RESULT OF LONG-TERM ELASTICITY FORM ARDL

\begin{tabular}{|c|c|c|c|}
\hline Division & & $\begin{array}{c}\text { Insurance } \\
\text { demand }\end{array}$ & $\begin{array}{l}\text { Deposits } \\
\text { demand }\end{array}$ \\
\hline \multicolumn{4}{|l|}{ Korea } \\
\hline \multirow{2}{*}{ INTEREST } & shock coefficient & $\begin{array}{c}-0.341^{*} \\
(-1.844)\end{array}$ & $\begin{array}{c}0.014 * * \\
(2.663)\end{array}$ \\
\hline & $\begin{array}{l}\text { long-term } \\
\text { coefficient }\end{array}$ & 12.597 & 0.018 \\
\hline \multirow{2}{*}{ IPI } & shock coefficient & $\begin{array}{l}7.512 * * \\
(2.048)\end{array}$ & $\begin{array}{c}0.155 \\
(1.624)\end{array}$ \\
\hline & $\begin{array}{l}\text { long-term } \\
\text { coefficient }\end{array}$ & 0.199 & 3.987 \\
\hline \multirow{2}{*}{ FX } & shock coefficient & $\begin{array}{c}-0.682 \\
(-0.600)\end{array}$ & $\begin{array}{c}0.118^{* * *} \\
(2.364)\end{array}$ \\
\hline & $\begin{array}{l}\text { long-term } \\
\text { coefficient }\end{array}$ & 4.265 & -0.356 \\
\hline \multirow{2}{*}{ STOCK } & shock coefficient & $\begin{array}{c}-0.108 \\
(-0.117)\end{array}$ & $\begin{array}{c}0.078 * * \\
(2.620)\end{array}$ \\
\hline & $\begin{array}{l}\text { long-term } \\
\text { coefficient }\end{array}$ & -0.400 & 1.943 \\
\hline UNEMP & shock coefficient & - & - \\
\hline
\end{tabular}

\begin{tabular}{|c|c|c|c|}
\hline & $\begin{array}{l}\text { long-term } \\
\text { coefficient }\end{array}$ & - & - \\
\hline \multicolumn{4}{|l|}{ Japan } \\
\hline \multirow{2}{*}{ INTEREST } & shock coefficient & $\begin{array}{c}0.538 \\
(0.642)\end{array}$ & $\begin{array}{l}0.775^{*} \\
(1.770)\end{array}$ \\
\hline & $\begin{array}{l}\text { long-term } \\
\text { coefficient }\end{array}$ & -0.218 & -0.011 \\
\hline \multirow{2}{*}{ IPI } & shock coefficient & $\begin{array}{l}-1.785^{*} \\
(-1.952)\end{array}$ & - \\
\hline & $\begin{array}{l}\text { long-term } \\
\text { coefficient }\end{array}$ & -0.849 & - \\
\hline \multirow{2}{*}{$\mathrm{FX}$} & shock coefficient & $\begin{array}{l}2.155^{*} \\
(1.897)\end{array}$ & $\begin{array}{c}0.983 * * \\
(2.182)\end{array}$ \\
\hline & $\begin{array}{l}\text { long-term } \\
\text { coefficient }\end{array}$ & 0.062 & 0.427 \\
\hline \multirow{2}{*}{ STOCK } & shock coefficient & $\begin{array}{c}-0.276 \\
(-0.677)\end{array}$ & $\begin{array}{l}-0.394 * \\
(-1.742)\end{array}$ \\
\hline & $\begin{array}{l}\text { long-term } \\
\text { coefficient }\end{array}$ & 0.314 & -0.171 \\
\hline \multirow{2}{*}{ UNEMP } & shock coefficient & - & $\begin{array}{l}-0.025 \\
(-0.799)\end{array}$ \\
\hline & $\begin{array}{l}\text { long-term } \\
\text { coefficient }\end{array}$ & - & -0.011 \\
\hline
\end{tabular}

Note : 1) parentheses contain t-statistics. $*$ significant at $10 \%$; $* *$ significant at $5 \%$.

<Table 5>, as a result of estimating the ECM, in the course of long-term equilibrium point, indicates the degree that is adjusted in the short term part of the withdrawal. Adjustment factor can grasp what the macroeconomics variables have adjustment process on life insurance new policies and household savings. The estimation results was able to find that impact of macroeconomics variables changes on life insurance and household savings demand deviations were very weak and slow thus they were adjusted by long term channel in Korea. In contrast, the degree of adjustment in short-term is high speed according to changing the macro-economic variables in Japan. Other words, both demands quickly return to its long-term equilibrium. Also all the sings were (-) indicating that each demand was affected by macroeconomic variables.

TABLE V

THE RESULTS OF ECM ESTIMATION

\begin{tabular}{c|c|c|c}
\hline Estimate the model & ecm(-1) & Estimate the model & ecm(-1) \\
\hline $\begin{array}{c}\text { Insurance demand } \\
\text { (K_NP) }\end{array}$ & $-0.036^{*}$ & Insurance demand & $-2.529 * *$ \\
$(-1.753)$ & (J_NP) & $(-7.294)$ \\
\hline $\begin{array}{c}\text { Deposits demand } \\
\text { (K_DEPOSIT) }\end{array}$ & $-0.104^{* *}$ & Deposits demand & $-1.870^{* *}$ \\
$(-4.610)$ & (J_DEPOSIT) & $(-5.555)$ \\
\hline
\end{tabular}


Note : 1) parentheses contain t-statistics. * significant at $10 \%$; ** significant at $5 \%$.

\section{Robustness test}

A common exercise in empirical studies is a "Robustness check", where the researcher examines how certain "core" regression coefficient estimates behave when the regression specification is modified by adding or removing regressors. If the coefficients are plausible and robust, this is commonly interpreted as evidence of structural validity. Here, we applied the completed model withal out of sample. <Figure 2> shows that a predictive model looks very similar to out of sample while the sudden change in the dependent variable. Also the root mean square (RMSE) error is low compared with restrictions VAR model. Using the RMSE helps to provide a complete picture of the error distribution. it's to compare model and observations. RMSE can reconstruct the error distribution close to its exact solution, when standard deviation exist within 5\%. <Table 6> shows RMSE of each forecasted value which is compared to the actual observations. The result of RMSE indicate that the degree of forecasting of model is quite accurate by RESMs near zero mean.
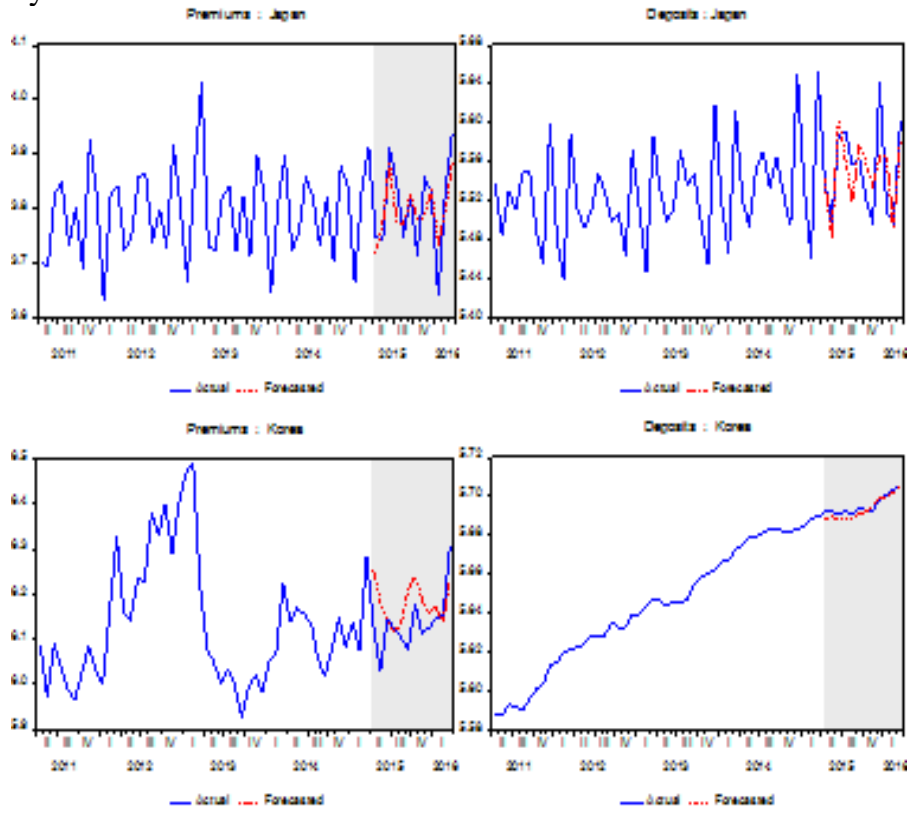

Fig 2. Simulation of forecasts

TABLE VI

THE RESULTS OF ECM ESTIMATION

\begin{tabular}{c|c|c|c}
\hline $\begin{array}{c}\text { Forecast variable } \\
\text { (K_NP) }\end{array}$ & RMSE & Forecast variable & RMSE \\
\hline $\begin{array}{c}\text { Insurance demand } \\
\text { Deposits demand } \\
\text { (K_DEPOSIT) }\end{array}$ & 0.079 & $\begin{array}{c}\text { Insurance } \\
\text { demand } \\
\text { (J_NP) }\end{array}$ & 0.063 \\
\hline
\end{tabular}

\section{V.CONCLUSIONS}

The aim of this paper has been to estimate the effect of changes in macro-economic variables on demands which are life insurance and savings deposits, using Korea and Japan data to compare. Additionally, this paper has tested the robustness of the model using historical simulation. Its main finding is that of a strong relationship between life insurance demand and interest rate and exchange rate in Korea. while life insurance demand of Japan respond more to IPI and stock index in long-term. In focusing on the long-term, policy indicators like interest rate and exchange rate although has flexible exchange rate system further impact to its demand in Korea. Japan insurance industry is more influenced by the real economy. Savings deposits demand is measured to different results. Secondly finding is that of a relationship with interest rate and exchange rate although its response is weak temporarily in Japan and savings deposits of Korea is related to IPI and stock index in long-term. The reason for this result is associated with small open economic and low interest rate. It strongly recognizes that the purpose of insurance is to guarantee care, illness, and pension in Japan. so it more dependent on the real economy. But insurance have recognized as revenue product like financial products.

The results of robustness test are approximation to the actual observation.

This paper has discussed the degree of change on life insurance and savings deposits in Korea and Japan. These product are consider a long-term product relatively.

This discussion is distinguished as finding the perception at two countries. Also can ensure the stability of each corporations which likewise is classified financial industry.

\section{REFERENCES}

[1] B. Lim, "A Comparative Analysis on the Determinant Factors of the Insurance and the Saving in Urban Household Survey," Korean Insurance Research Institute, Vol. 15-2, pp. 145-171.

[2] D. B. Truett and L. J. Truett, "The Demand for Life Insurance in Mexico and the United States: A Comparative Study," The Journal of Risk and Insurance, Vol. 57, pp. 321-328. https://doi.org/10.2307/253306

[3] D. Ward and R. Zurbruegg, "Dose Insurance Promoto Economic Growth Evidence from OECD Countries," The Journal of Risk and Insurance, Vol. 67, pp. 489-506. https://doi.org/10.2307/253847

[4] E. Hong, "A Study on the Lead-Lag Relationship between KOSDAQ50 Spot and Futures Markets with Vector Error Correction Model," Industry Economic Research, Vol. 18-5, pp. 2025-2040.

[5] G. Jeong, "Household Savings rate Declines and Monetary Policy Effectiveness," The Bank of Korea, Economic Research Institute, Economic Analysis, Vol. 13-2, pp.44-78.

[6] H. Joung, H. Jeong and M. Chi, "The study of Empirical studies of the relationship between insurance, savings and GNP," Journal of insurance, Vol. 56, pp. 91-116.

[7] H. Kim and E. Park, "An Empirical study on demand factors for Life Insurance and Bank Deposits using ARDL-Bounds test," Korea Insurance Institute, Vol. 97, pp.133-157.

[8] H. Rhee, "Empirical Analysis on Monetary Policy and Effectiveness to International Reserve Implemented by ARDL-Bounds Test," International Area Studies Review, Vol. 11-2, pp. 139-159.

[9] J. D. Hammond, D. B. Houston and M. F. Eugene, "Determinants of Household Life Insurance Premium Expenditure: An Empirical Investigation," Journal of Risk and Insurance. Vol. 34-3, pp. 397-408.

[10] J. F. Outreville, "Life Insurance Markets in Developing Countries," The Journal of Risk and Insurance, Vol. 63, pp. 236-278. https://doi.org/10.2307/253745

[11] J. Mackinnon, "Critical Values for Co-Regration Tests, Long Run Economic Relationship: Readings in Co-Regration, edited by R. F. Engle and C. W. granger, Oxford University Press, pp. 267-276.

[12] J. Hwang and D. Seo, "Impact of Macro-economic Variable on Initial Premiums in Variable in Life Insurance with a Vector Error Correction Model,” Korean Insurance Research Institute, Vol. 21-3. pp. 3-32. 
[13] K. Yoon, "Study on the Relationship between Retained Premium of the Donestic Non-life Insurers and Macroeconomic Variables," Dankook University Ph.D, dissertation.

[14] M. H. Pesaran and Y. Shin, "An Autoregressive Distributed-Lag Modelling Approach to CoRegration Analysis." Econometrics and Economic Theory in the 20th century: The Ragnar Fisch Centennial symposium (edited by Steinar strom), Cambridge University Press, pp. 371-413.

[15] M. H. Pesaran, Y. Shin and R. J. Smith, "Bouns test approaches to the Analysis of Level Relationships," Journal of Applied Econometrics, Vol. 16. pp. 289-326. https://doi.org/10.1002/jae.616

[16] M. J. Browne and K. Kim, "A Rational Analysis of Life Insurance Demand," The Journal of Risk and Insurance, Vol. 60, pp. 616-634. https://doi.org/10.2307/253382

[17] R. F. Engle, and W. J. Granger, "Co-Regration and Error Correction : Representation, Estimation and Testion," Econometrica, Vol. 55, PP. 35-47.

[18] S. Jung and S, Ouh, "An Empirical Study on the Lapse Rate in the Life Insurance Industry," Korean Insurance Journal, Vol. 82 pp. 155-178.

[19] S. Lee and S. Yang, "An Analysis on Determinants of Life Insurance Demand Using Panel data : Focusing on Whole Life, Sickness, Accident and Variable Life," Korean Insurance Journal, Vol. 90, pp. 51-75.

[20] S. Nam, "A study on the causality between the insurance industry and economic growth," Korean Insurance Journal, Vol. 74, pp. 169-197.

[21] X. Lu and H. White, "Robustness checks and robustness tests in applied economics," Journal of Econometrics, 2014 https://doi.org/10.1016/j.jeconom.2013.08.016 